\title{
HIPPOCAMPAL SCLEROSIS AND STATUS EPILEPTICUS
}

\section{CAUSE OR CONSEQUENCE ?}

\author{
A MRI study
}

\author{
Gustavo Wruck Kuster', Pedro Braga-Neto', Denizart Santos-Neto', \\ Maria Teresa Garcia Santana', Antonio Carlos Martins Maia Jr', \\ Orlando Graziani Povoas Barsottini'
}

\begin{abstract}
Background: Transient imaging abnormalities, including changes on diffusion-weighted imaging (DWI), may be seen in status epilepticus. These abnormalities can be followed by hippocampal sclerosis. Case report: We report a 15-year-old lady with focal non convulsive status epilepticus (NCSE) and focal slowing on EEG. DWI exhibited abnormal hyperintense signals in bilateral temporal and insular cortices. After 3 weeks, MRI performed a localizated hippocampal atrophy. Conclusion: The MRI findings indicated vasogenic and cytotoxic edema during seizure activity and subsequent loss of brain parenchyma.
\end{abstract}

KEY WORDS: status epilepticus, magnetic resonance imaging (MRI), diffusion-weighted images, reversible MRI abnormalities, hippocampal sclerosis.

\begin{abstract}
Esclerose hipocampal e status epilepticus: causa ou conseqüência? Um estudo de RM
RESUMO - Introdução: Anormalidades transitórias de imagem, incluindo imagens de ressonância magnética por difusão (DWI), podem ser vistas no status epilepticus. Essas anormalidades podem ser seguidas de esclerose hipocampal. Relato de caso: Nós relatamos uma jovem de 15 anos com status focal não convulsivo e lentificação focal no EEG. DWI mostrava sinal hiperintenso em regiões temporais bilaterais e córtex insular. Após 3 semanas, RM de encéfalo mostrava atrofia localizada do hipocampo. Conclusão: Os achados de RM indicam edema vasogênico e citotóxico durante as crises epilépticas com subseqüente atrofia de parênquima cerebral.
\end{abstract}

PALAVRAS-CHAVE: status epilepticus, ressonância nuclear magnética (RNM), sequência difusão, alterações reversíveis de RNM, esclerose hipocampal.

Brain magnetic resonance imaging (MRI) is mandatory as a diagnostic workup for patients with epileptic seizures in order to delineate any structural epileptogenic lesion. Transient signals abnormalities can occur and have been attributed to functional changes due to seizure activity'. Convulsive status epilepticus causes brain MRI changes after generalized and focal motor seizures ${ }^{2}$, although these findings in nonconvulsive status epilepticus (NCSE) are exceptional ${ }^{3,4}$. Focal NCSE occurs mostly as complex partial status epilepticus (CPSE) and several articles have reported transient MRI abnormalities after such situation ${ }^{5,6}$.

We report a case of a young female who presented a unique, long-lasting series of partial seizures with marked transient MRI abnormalities, followed by localized brain atrophy in despite of complete clinical recovery.

\section{CASE}

A 15 year old right-handed female was admitted in our Neurological Unit presenting apathy and speech arrest since 5 days before the admission. Her medical records were unremarkable for perinatal pathological events, febrile seizures, cardiac diseases, cerebral injuries or infectious diseases. Psychomotor development was normal. Family history was negative for epilepsy.

At hospital admission, she had no fever and arterial blood pressure was normal. In neurological examination, she presented with drowsiness, masticatory movements and right hand dystonia.

EEG showed the presence of continuous spikes with al-

'Division of General Neurology, Department of Neurology of Federal University of São Paulo, São Paulo SP, Brazil; 'Fleury Institute, Magnetic Resonance Imaging Unit, São Paulo SP, Brazil.

Received 4 June 2007, received in final form 17 August 2007. Accepted 18 September 2007.

Dr. Gustavo Wruck Kuster - Rua Onze de Junho 643 / apt 164 - 04041-052 São Paulo SP - Brasil. E-mail: gwkuster@hotmail.com 


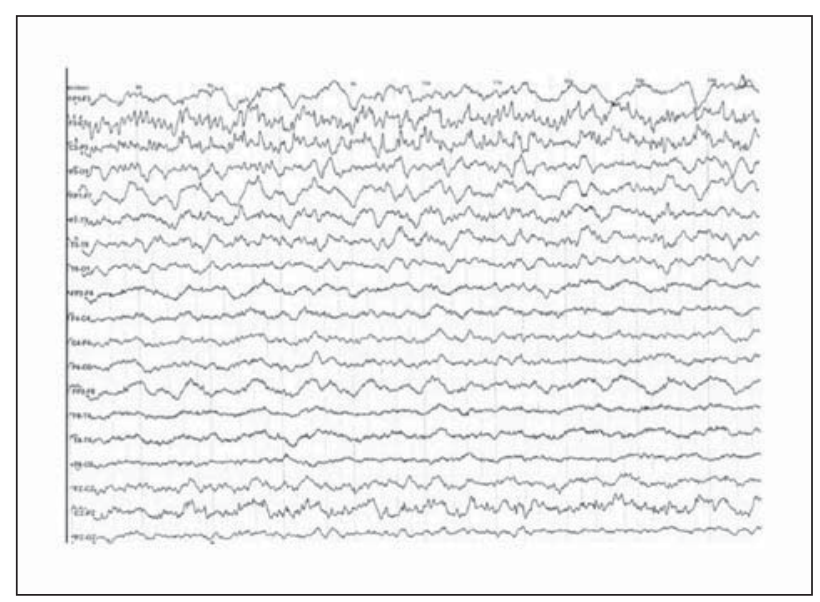

Fig 1. EEG showed the presence of continuous spikes with alpha / theta activity of 6-9 Hz over the left central and middle line regions.

pha / theta activity of 6-9 Hz over the left central and middle line regions (Fig 1).

Benzodiazepines, followed by intravenous phenobarbital were done with no improvement. She required intubation, mechanical ventilation and continuous infusion of benzodiazepines in a Intensive Care Unit (ICU).

A CT scan of the brain on the day of admission showed a left temporal hypodensity with slight contrast enhancement. Cerebrospinal fluid (CSF) analyzed on day 1 was acellular with normal levels of glucose and protein. Further CSF samples on the day 7 and 14 were also acellular. Routine haematology and blood biochemistry were normal. Microbiological studies were negative. Human Imunodeficiency Virus (HIV), Hepatitis B virus (HBV) and Hepatitis C virus (HCV) serologies were negative.

On the seventieth day the patient had an EEG improvement, a partial consciousness recovery and mechanical ventilation was discharged. By this time, the first brain MRI scan was done.

Three weeks later, after a complete clinical recovery, a follow-up MRI was performed.

MRI abnormalities - At the admission, serial MRI scans $(1,5 T$, Sonata, Siemens, Erlanger, Germany) were performed. After repeated episodes of NCSE, diffusion-weighted images and T2-weighted images FLAIR exhibited abnormal hyperintense signals in bilateral temporal and insular cortices. These abnormalities appeared more extensive on diffusionweighted images than on T2-weighted images FLAIR. The hippocampi appeared abnormal and also presented bilateral abnormal hyperintense signals, without atrophy, more extensive on the left hippocampus. There was no disruption of blood-brain barrier (BBB) on T1-weighted images after intravenous administration of Gd-DTPA (Fig 2).

After 3 weeks, there were no signal abnormalities on diffusion-weighted images and T2-weighted images FLAIR. However, enlargement of the subarachnoid space just near the left temporal lobe and enlargement of the temporal horn of the right lateral ventricle were evident, indicating localized brain atrophy (hippocampal atrophy) (Fig 3).

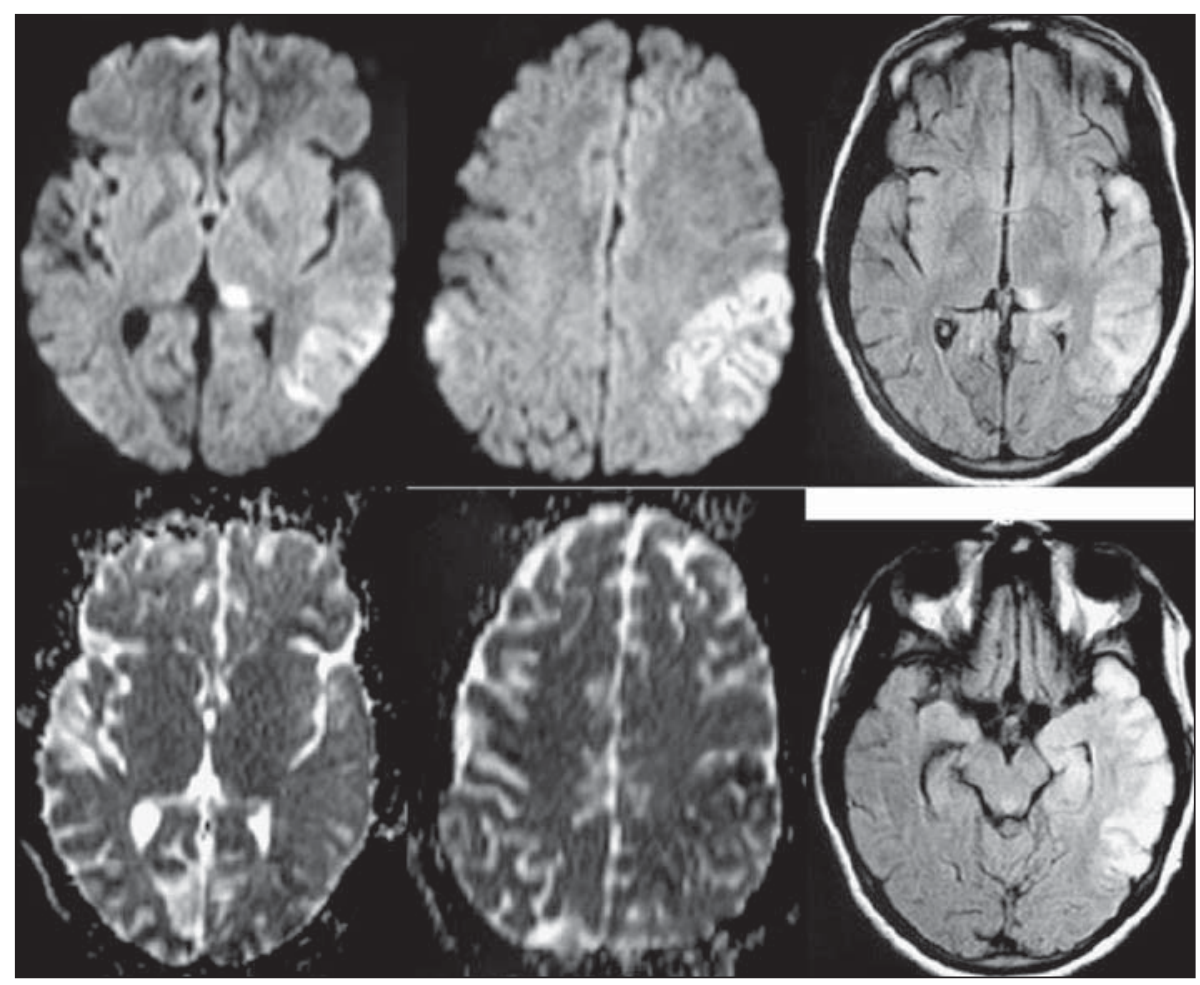

Fig 2. Diffusion-weighted images (DWI) and T2-weighted images FLAIR exhibited abnormal hyperintense signals in bilateral temporal and insular cortices. 


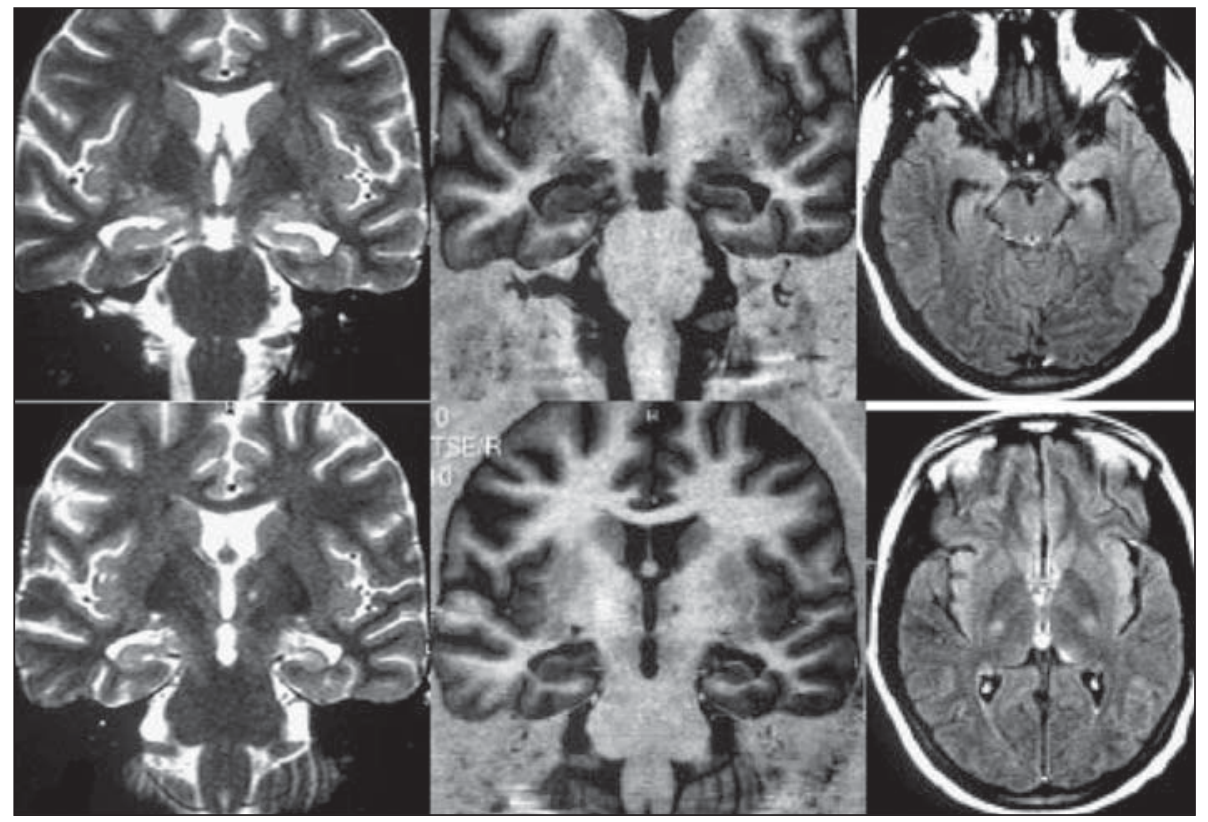

Fig 3. MRI (coronal / axial) exhibited enlargement of the subarachnoid space just near the left temporal lobe and enlargement of the temporal horn of the right lateral ventricle were evident, indicating hippocampal atrophy.

\section{DISCUSSION}

We describe here a case of non-convulsive status epilepticus characterized by clinical, electroencephalographical and MRI findings. Brain MRI showed reversible diffusion and $\mathrm{T}_{2}$-weighted images abnormalities in bilateral temporal and insular lobes, which disappeared after three weeks, giving place to cortical atrophy. The patient experienced clinical as well as EEG recovery after this period.

Partial seizures and status epilepticus are associated with a local change of blood flow and neuronal metabolism. This is clearly demonstrated by numerous PET and SPECT studies which have shown increased cerebral flow and metabolite consumption in the area of epileptic focus ${ }^{7-9}$. These findings have been confirmed by functional MRI, with important clinical implications ${ }^{10}$.

The above-mentioned metabolic phenomena are proportional to the frequency and duration of the seizures $^{1,11,12}$. They determine a transitory alteration of the $B B B$, an increased of vascular permeability and the subsequent appearance of cerebral edema. BBB could be differently compromised and this could explain the MRI findings reported in literature, which vary from signal alteration caused by vasogenic and/or cytotoxic edema to contrast enhancement, as a result of either damage or breakdown of the BBB, respectively ${ }^{13,14}$.

The association of hippocampal abnormalities with chronic epilepsy and status epilepticus is well stablished ${ }^{15-19}$. The nature of the neuropathological changes found depends on how long standing they are. In early cases there are ischemic changes in neurones in vulnerable areas (hippocampus, thalamus and striatum) with acute astrocytic reation. In the later cases there is neuronal loss and gliosis in these areas. It is generally accepted that status epilepticus directly results in hippocampal sclerosis ${ }^{20,21}$, but many of the reports are of cases with encephalitis, with severe complications of status epilepticus such hypoxia, hypoglycemia or with other major systemic illness ${ }^{17}$.

In our case, no underlying cause was found. The CSF and serological studies showed no evidence of encephalitis. The patient did not develop major systemic disturbances such as hypoxia or hypoglycemia ${ }^{22}$. These factors suggest that in this case, the abnormalities detected on MRI are a direct result of the patient's status epilepticus. An alternative explanation would be that the hippocampal changes caused the status epilepticus, rather then the other way around. We believe that the clinical picture, the appearance of new changes in MRI after the onset of the status epilepticus, make this explanation unlikely.

\section{REFERENCES}

1. Jackson GD, Conelly A, Cross JD, Gordon I, Gadian GD. Functional magnetic resonance imaging of focal seizures. Neurology 1994;44:850856.

2. Kim JA, Chung JI, Yoon PH. Transient MR changes in patients with tonicoclonic seizures or status epilepticus: periictal diffusion weight imag- 
ing. Am J Neuroradiol 2000;22:1149-1160.

3. Callahan DJ, Noetzel MJ. Prologed abcense status epilepticus associated with carbamazepine therapy, increased intracranial pressure, and transient MRI abnormalities. Neurology 1992;42:2198-2201.

4. Castro-Costa CM, Vale OC, Leitão V, et al. Epilepsia partialis continua (Koshevhikov): a preliminary case report. Arq Neuropsiquiatr 2000;58: 916-918.

5. Chu K, Kang DW, Kim JY, Chang KH, Lee SK. Diffusion-weighted MRI in nonconvulsive status epilepticus. Arch Neurol 2001;58:993-998.

6. Lansberg MG, O'Brien MW, Norbash AM. MRI abnormalities associated with partial status epilepticus. Neurology 1999;52:1021-1027.

7. Theodore WH, Newmark ME, Sato S, Brook R. Fluorodeoxyglucose positron emission tomography in refractory complex partial seizures. Ann Neurol 1983;14:429-437.

8. Lee BI, Markand OM, Welman HN, Krepshaw J. HIPDM-SPECT in patients with medically intractable complex partial seizures. Arch Neurol 1988:45:397-402

9. Juhasz C, Scheidl E, Szirmai I. Reversible focal MRI abnormalities due to status epilepticus: an EEG, SPECT, transcranial Doppler follow up study. Electroenceph. Clin Neurophysiol 1998;107:402-407.

10. Detre JA, Alsop DC, Aguirre JK. Coupling of cortical and thalamic ictal activity in human partial epilepsy: demonstration of functional MRI. Epilepsia 1996;37:657-661.

11. Sammaritano M, Andermann F, Melanson D, Pappius HM. Prolonged focal cerebral edema in partial status epilepticus. Epilepsia 1985:26;334-339.

12. Kramer RE, Luders H, Lesser RP, Weinstein MR, Dinner DS. Transient focal abnormalities of neuroimaging studies during focal status epilep- ticus. Epilepsia 1987;28:528-532.

13. Yaffe K, Ferriero D, Barkovic AJ. Reversible MRI abnormalities following seizures. Neurology 1995;45:104-109.

14. M El- Koussy. Focal status epilepticus: follow up by perfusion and diffusion MRI. Eur Radiol 2002;12:568-574.

15. Corsellis JAN, Bruton CJ. Neuropathology in status epilepticus in humans. In Delgado-Escueta AV, Porter RJ (Eds). Advances in Neurology. Vol 34. Status epilepticus. New York, 1983:129-139.

16. Margerison JH, Corsellis JAN. Epilepsy and the temporal lobes: a clinical eletroencephalography and neuropathological study of the brain in epilepsy. Brain 1966:84;429-530.

17. Nobuyuki K. Magnetic resonance imaging and PET findins in status epilepticus following hypoglycemia. Ann Nuclear Med 2006;20: 371-376.

18. Nixon J, Bateman D, Moss T. An MRI and neuropathological study of a case of fatal status epilepticus. Seizure 2001:10;588-591.

19. Keun-Sik H. Diffusion changes sugesting vasogenic oedema during partial status epilepticus. Seizure 2004;13:317-321.

20. Parmar H. Acute symptomatic seizures and hippocampus damage: DW and MRS findings. Neurology 2006;66:1732-1735.

21. Bauer G, Godwald TH, Dodensberg J, et al. Transient and permanent MRI abnormalities after complex partial status epilepticus. Epilep Behav 2006;8:666-671.

22. Joselita JCF, Carvalho FF, Perosa SR, et al. Efects of glycemic state in rats submitted to status epilepticus during development. Arq Neuropsiquiatr 2006;64:233-239. 